\title{
THE ROLE OF REGIONAL CENTERS AND UNIVERSITY CHILDREN'S HOSPITAL IN DEVELOPMENT OF HOME MECHANICAL VENTILATION NETWORK
}

\author{
Rsovac Snežana, Đukić Milan, Kalanj Jasna, Međo Biljana, Petrović Marko, Petrov Ivana \\ University Children's hospital, Belgrade, Serbia
}

Primljen/Received 20. 05. 2017. god.

Abstract: Application of home mechanical ventilators represents the future in the treatment of children with chronic respiratory insufficiency. In this way patients are treated in the home environment, they have full support from their families, they are protected against nosocomial infections and their condition is monitored by medical staff. The role of regional centers is very important in the future development of the home mechanical ventilation network. Doctors in these centers under the full support of the University Children's Hospital physicians can assist and monitor the treatment of children on the household respirators.

Key words: home mechanical ventilation, family support, children.

\section{INTRODUCTION AND CONTEXT}

Children who need home ventilation represent the group of patients with special needs. There is no unified program for the treatment of these children in our country and there is no home ventilation network. Also there is no guide that applies to all segments of the treatment of these complex patients.

Use of home mechanical ventilators has started for more than twenty years ago in the rest of the world. Highly developed countries have the most experience in using this form of chronic respiratory therapy. Based on five years of experience, from 2011 to 2015, in treating children with chronic respiratory failure in the neonatal and pediatric intensive care unit at the University Children's Hospital, it was concluded that the development of a network of home mechanical ventilation and home care for these patients would be the best approach for solving the problem. American Thoracic Society a few years ago formed an expert interdisciplinary team as a working group, which developed home ventilation network for children with chronic respira-
Prihvaćen/Accepted 27. 07. 2017. god.

tory failure $(1,2)$. The main issues were finding the best way to treat these children, organize the network, include patient's family members, evaluate their treatment and finally make clear guidelines and recommendations for the treatment.

The analysis of data from the University Children's Hospital, Department of Pediatric and Neonatal Intensive Care, for the period from 2011 to 2015, showed that we had 68 patients who required prolonged mechanical ventilation for more than 30 days. The total number of days of mechanical ventilation for these patients was 3491 days or 83784 hours of mechanical ventilation. Minimum duration of the mechanical ventilation was 30 days and the longest 180 days. Average number of days of mechanical ventilation per patient was 51.4, or 1,233.6 hours. The longest duration of mechanical ventilation was 698 days. These data are not related to neurosurgical patients who are being treated at the department of surgical intensive therapy. In the period of five years, from these 68 patients 21 of them had indication for home mechanical ventilation, from which only 9 went on home mechanical ventilation therapy. The others remained hospitalized in our institution or in the regional centers that have ventilators. Why is that so?

Current procurement procedures for getting home ventilators relate to ventilator for non-invasive ventilation (NIV) which is being approved by the Commission of the Health Insurance Fund. This kind of ventilators can insured for patients suffering from severe forms of muscular dystrophy (Duchenne), spinal muscular atrophy, amyotrophic lateral sclerosis (ALS), high lesions of the cervical spine. Procedure for getting the ventilator for home use has few steps. First they need to have an opinion from neurologist and pulmonologist or pneumophtisiologist, then opinion from the 
Commission for non-invasive ventilation and finally from medical commission who gives permission for getting the ventilator. In this way patients can get only ventilator for non-invasive ventilation (3).

If the patient needs ventilator for invasive mechanical ventilation, parents have to buy it. But they also need aspirator, tubes for suction, pulse oxymeter etc. Parents must be trained to handle the ventilator, and service, in case of any failure of the ventilator has to be available. It is also necessary to provide specialized nurse, physiotherapist, nutritionist, psychologist and social worker. Doctors from the primary health care have very important role in this network as they have to monitor the patient's condition all the time. In addition, it is necessary to make notes about patient's medical condition every day (4).

This multidisciplinary approach is necessary for the successful treatment. Based on the data from literature, this form of treatment has many advantages over the long term hospitalization. Comparing the costs of mechanical ventilation (hospital costs of average $\$ 21,570$ per month, per patient and costs of home treatment of average $\$ 7,050$ ) show that the savings are around $\$ 14,520$. Other benefits are improving the quality of life of the patient and family, better socialization; pediatric patients can be with their parents all the time which is very important for their psychological state. Home mechanical ventilation is reducing hospital infections and enables intensive care units to have higher capacity for the treatment of acute patients $(1,4)$.

On the basis of existing guidelines, the indications for mechanical ventilation at home are very clear (Table 1) (1). There are also clinical protocols that relate to training for parents as well as doctors from primary health care, who represent a very important factor in the treatment of these patients.

Standardization of procedures, with the support of the Ministry of Health of the Republic Serbia and Health Insurance Fund, who has to invest in this type of treatment, is done by a team of experts who need to make guidelines for the treatment of these patients and training program for their parents and all members of medical team involved in using home mechanical ventilators.
Table 1. Indications for mechanical ventilation in pediatric patients at home

\begin{tabular}{|c|}
\hline Indications \\
\hline Increased Respiratory Load \\
\hline $\begin{array}{l}\text { Bronchopulmonary dysplasia } \\
\text { Hypoxia and hypercapnia } \\
\text { COPD } \\
\text { Restrictive parenchymal lung diseases }\end{array}$ \\
\hline Ventilatory Muscle Weakness \\
\hline $\begin{array}{l}\text { Motor neuron diseases } \\
\text { Primary myopathies } \\
\text { Spinal cord injury }\end{array}$ \\
\hline Failure of Neurological Control of Ventilation \\
\hline $\begin{array}{l}\text { Congenital central hypoventilation syndrome } \\
\text { Myelomeningocele } \\
\text { Acquired central hypoventilation syndrome } \\
\text { (brain tumor etc) }\end{array}$ \\
\hline
\end{tabular}

With the future development of telecommunication and telemedicine, these patients could be handled much easier and that would be a great benefit for patient's mental health as well as for their family members (5).

\section{CONCLUSION}

In order to make adequate organization of home mechanical ventilation network, it is necessary to do a feasibility study, study of quality of life of these patients and also a cost benefit of this treatment. Guidelines, based on good clinical practice, are very important for the implementation of home mechanical ventilation.

\section{Conflict of Interest}

The author declares no conflict of interest.

\section{Licensing}

This work is licensed under a Creative Commons Attribution 4.0 International (CC BY 4.0) License.

\title{
Sažetak
}

\section{ULOGA REGIONALNIH CENTARA I UNIVERZITETSKE DEČIJE BOLNICE U RAZVOJU MREŽE KUĆNE MEHANIČKE VENTILACIJE}

\author{
Rsovac Snežana, Đukić Milan, Kalanj Jasna, Međo Biljana, Petrović Marko, Petrov Ivana \\ Univerzitetska dečija bolnica, Beograd, Srbija
}

Primena kućnih mehaničkih ventilatora predstavlja

suficijencijom. Na ovaj način se pacijenti leče u kućnom budućnost lečenja dece sa hroničnom respiratornom inokruženju, imaju punu podršku porodice, zaštićeni su od 
nozokomijalnih infekcija i njihovo stanje se prati od strane medicinskog osoblja. Uloga regionalnih centara je veoma značajna u budućem razvoju mreže kućne mehaničke ventilacije. Lekari u ovim centrima, uz punu podr-

\section{REFERENCES}

1. Sterni LM, Collaco JM, Baker CD, Carroll JL, Sharma GD, Brozek JL, et al. An official American Thoracic Society clinical practice guideline: pediatric chronic home invasive ventilation. Am J Respir Crit Care Med. 2016; 193(8): e16-35.

2. Kun SS, Davidson-Ward SL, Hulse LM, Keens TG.. How much do primary care givers know about tracheostomy and home ventilator emergency care? Pediatr Pulmonol. 2010; 45(3): 270-4.

\section{Correspondence to / Autor za korespondenciju}

Snežana Rsovac

University children's hospital

Tirsova 10

11000 Belgrade, Serbia

Email: snezanarsovac@yahoo.com šku lekara Univerzitetske Dečije Bolnice, mogu asistirati i pratiti lečenje dece koja su na kućnim respiratorima.

Ključne reči: kućna mehanička ventilacija, porodična podrška, deca.

3. Regulation on medical-technical aids which are provided from the mandatory health insurance. Sl. Glasnik RS 52/2012, 62/2012 corr, 73/2012.corr, 1/2013, 7/2013-corr., 112/2014, 114/2014-corr 18/2015.

4. King A. Long-term home mechanical ventilation in the United States. Respiratory Care. 2012; 57(6): 921-32.

5. Casavant DW, McManus ML, Parsons SK, Zurakowski D, Graham RJ. Trial of telemedicine for patients on home ventilator support: feasibility, confidence in clinical management and use in medical decision-making. J Telemed Telecare. 2014; 20(8): 441-9. 